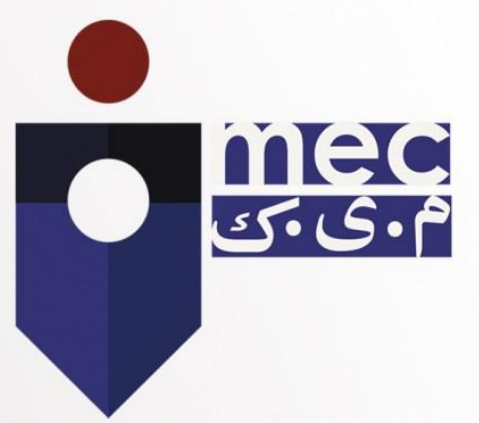

كميتهُ مستقل مشتر كى نظارت و ارزيابى مبارزه عليه فساد ادارى مثار

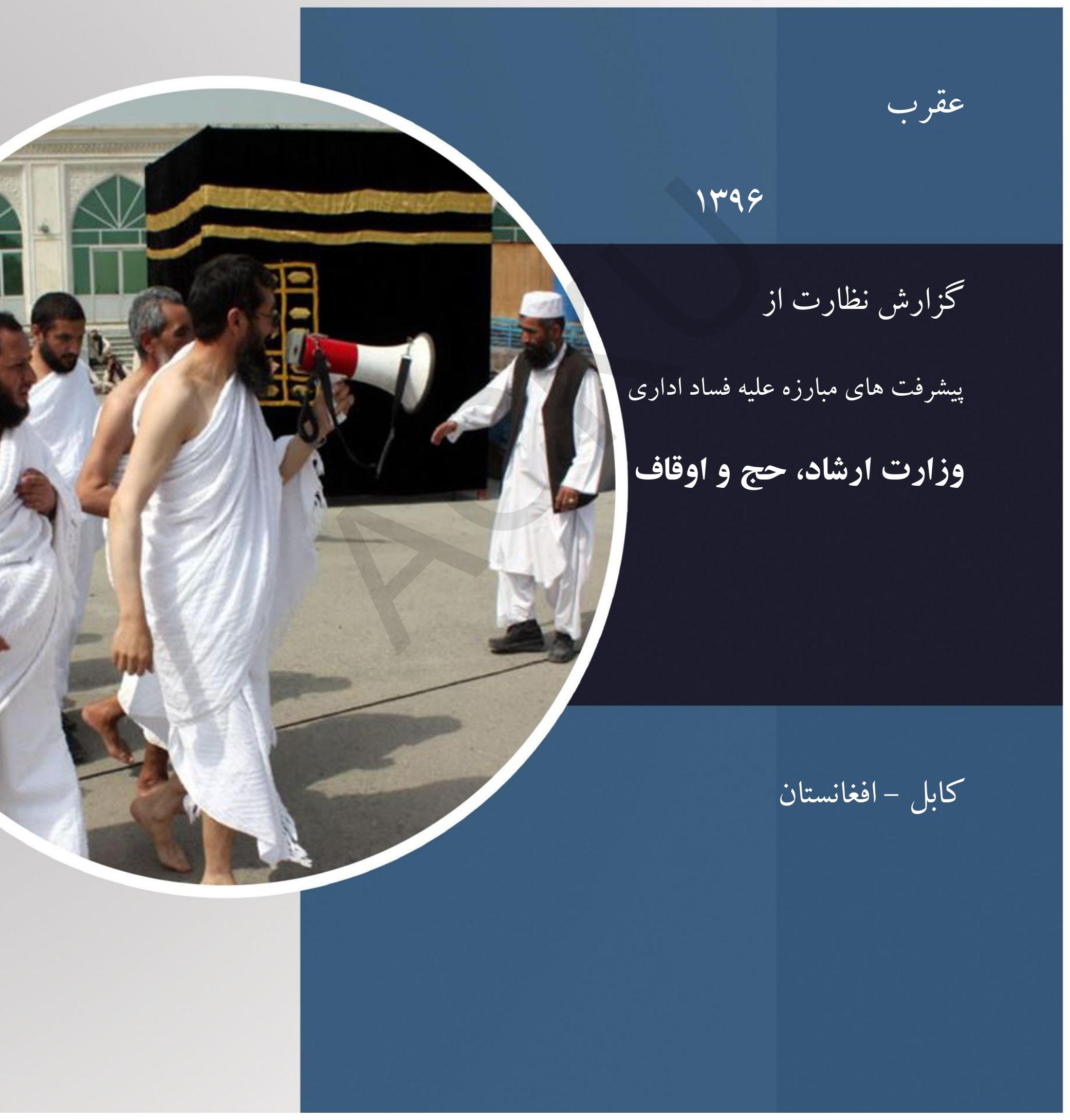




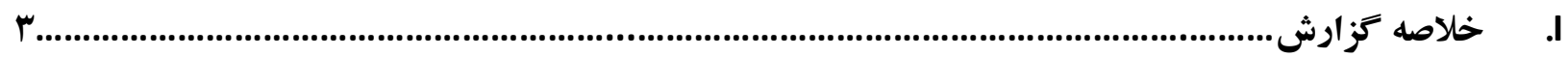

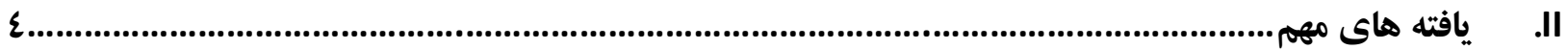

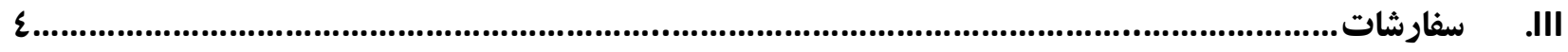

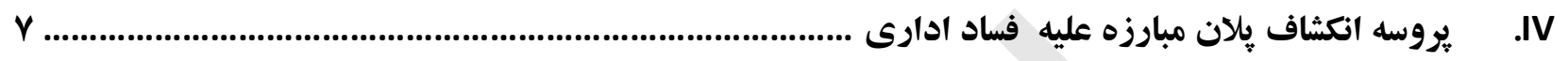

V

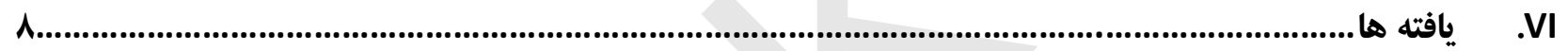

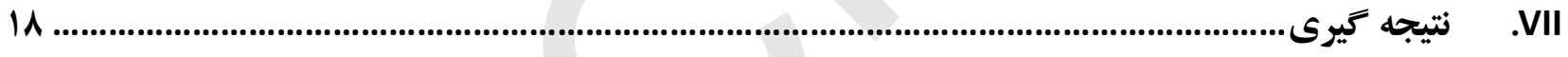




\section{خلاصه كزارش}

سال كذشته كميته مستقل مشترك نظارت و ارزيابى مبارزه عليه فساد ادارى يلان هاى مبارزه عليه فساد ادارى وزارت ها را مورد بازنكرى قرار داد كه در آن وزرات ماليه، وزارت تجارت و صنايع، وزارت مخابرات و تكنالوزى معلوماتى و وزارت امور مهاجرين و عودت كنند كان شامل بوده اند. ' در اين رايور كميته مستقل نظارت و ارزيابى مبارزه عليه فساد ادارى، پِلان مبارزه عليه فساد ادارى وزارت ارشاد، جحج و اوقاف را مورد بازنخرى قرار داده است.

بر اساس مكتوبى كه وزارت ارشاد، حج و اوقاف آنرا به وزارت ماليه فرستاده است ، بّهه معين ادارى و مالى وزارت ارشاد، حج و اوقاف وظيفه سبرده شده است كه يك كميته را تاسيس نموده تا از تطبيق پِلان مبارزه عليه فساد ادارى آن وزارت نظارت به عمل آورد و از رياست هاى مسئول گزارشات را جمع آورى نمايد. در اين مكتوب اين موضوع خيلى روشن گرديده است كه معيين ادارى و مالى بايد اين كميته را ايجاد نموده و سريرستى آنر به دوش گيرد. مسوليت اين كميته نظارت منظم از يّلان ها است، اما در اين مكتوب

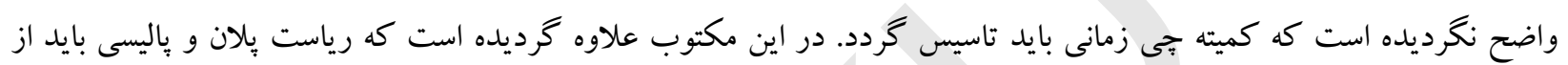
تطبيق اين هِلان در اين وزارت نظارت نمايد و به كميته موظف گزارشات را ارايه نمايد. كميته مستقل مشترك نظارت و ارزيابى مبارزه عليه فساد ادارى خواستار اين گزارش گرديد اما وزارت ارشاد، حج و اوقاف هيج گزارش در اين رابطه نداشت كه به كميته مستقل

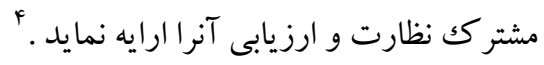
در اين بازنخرى واضح گُرديد كه وزارت ارشاد، حج و اوقاف لست مكمل ملكيت هايش را ندارد. همجنان اين نيز روشن گرديد كه اين وزارت در رابطه به اعاده ملكيت هاى غصب شده نيز مشكلات جدى دارد. اين دو برسش با هم مرتبط اند و براى جمع آورى عوايد اين وزارت خيلى مهم اند. يافته مهم اين بازنخرى اين است كه بِلان مبارزه عليه فساد ادارى بطور درست طرح نخرديده است و داراى مشكلات تخنيكى زيادى مى باشد. نخست اينكه يكك مبداى واضح ندارد، دوم اين كه اين بِان بايد مبنى بر ارزيابى معروضيت هاى فساد ادارى طرح گردد.

كميته مستقل مشتركك نظارت و ارزيابى آرزومند است كه وزارت ارشاد، حج و اوقاف يافته ها و سفارشات اين بازنخرى را در نظر كيرد تا در يلان جديد مبارزه با فساد ادارى در آينده آنرا درج نمايد.

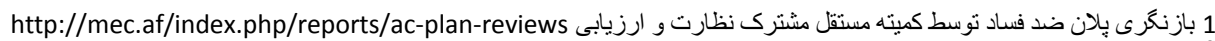

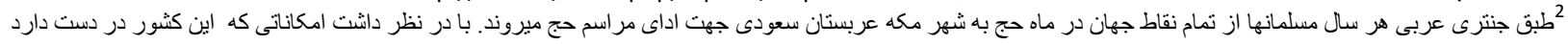

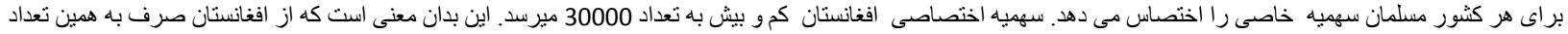

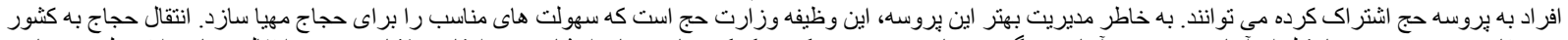

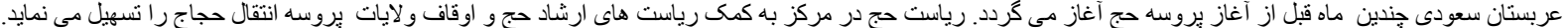

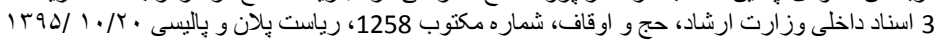

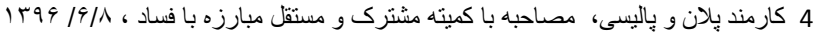




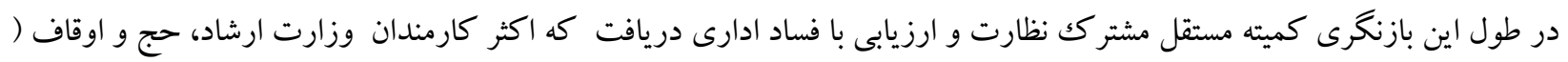

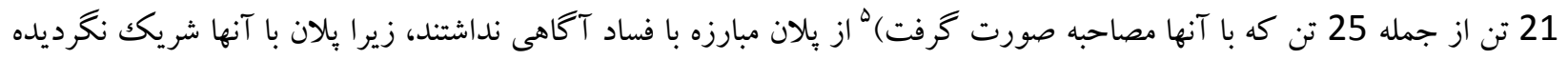
بود. ارزيابى خطرات ناشى از فساد ادارى يكى از اجزاى لازمى براى ايجاد بِلان مبارزه با فساد است، زيرا ارزيابى مى تواند عناصر مهم

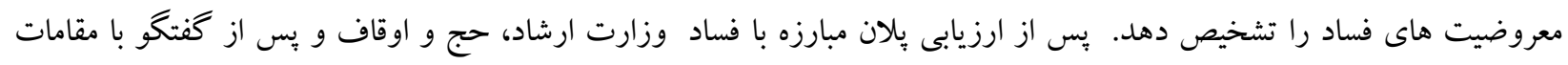
ارشد رياست بلان و ياليسى اين وزارت كميته مستقل مشترك مبارزه با فساد اين رادريافت كه قبل از طرح بلان هيج ارزيابى خطرات

اين هِلان يك سلسله مشكلات تخنيكى نيز دارد مانند اهداف، فعاليت ها، مبدا و شاخص ها كه نمى تو انند به هدف مبارزه با فساد ادارى رسيدگى نمايد. علاوه بر اين، شاخص ها مبهم اند وقابليت اندازه گيرى از لحاظ كمى و كيفى را ندارند. از همين رو تعقيب يروسه تطبيق بِان كار مشكل است.

سفارشات

\begin{tabular}{|c|c|c|}
\hline سفارشات & كتگورى & شماره \\
\hline 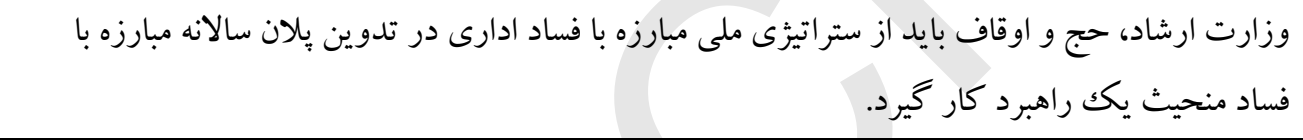 & عام & 1 \\
\hline تا وزارت ارشاد، حج و اوقاف به خاطر تشخيص ساحات معروض به فساد بايد ارزيابى خطرات را انجام دهد & عام & 2 \\
\hline شموليت رياست تفتيش داخلى در طرح بلان مذكور، تشخيص ساحات معروض به فساد و ايجاد ميكانيزم & عام & 3 \\
\hline 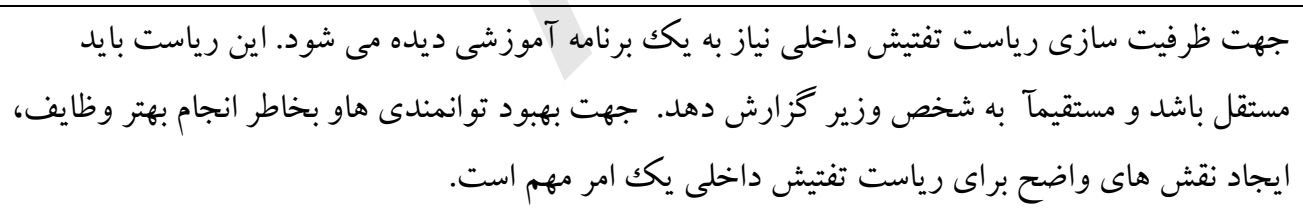 & عام & 4 \\
\hline 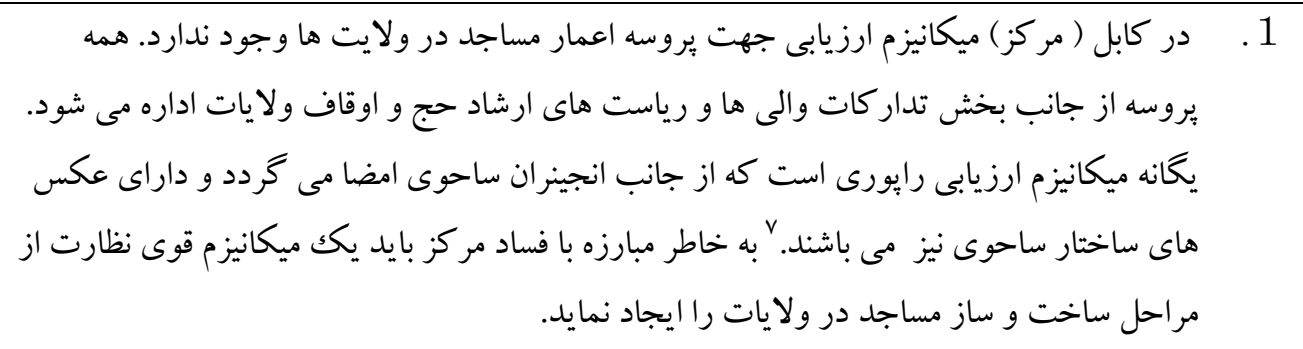 & هدف دوم & 5 \\
\hline
\end{tabular}

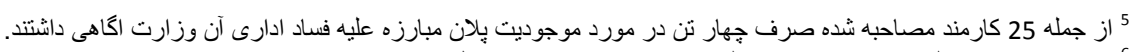

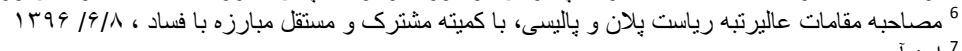




\begin{tabular}{|c|c|c|}
\hline 2. هيج طرزالعمل كتبى يا ميكانيزم جهت اعمار مساجد و ديخر اماكن مقدسه در ساحات وجود ندارد & & \\
\hline 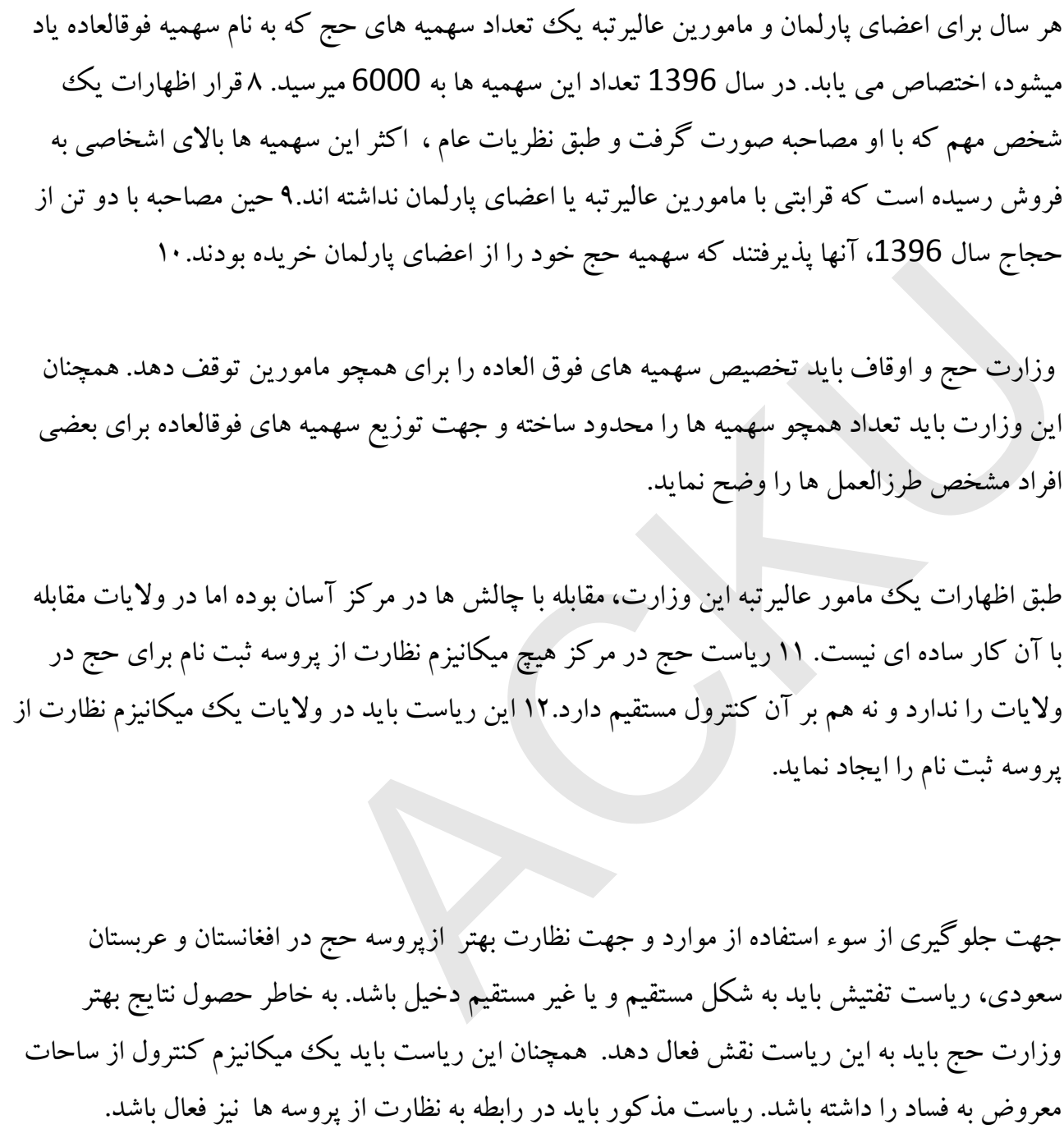 & هدف دوم & 6 \\
\hline 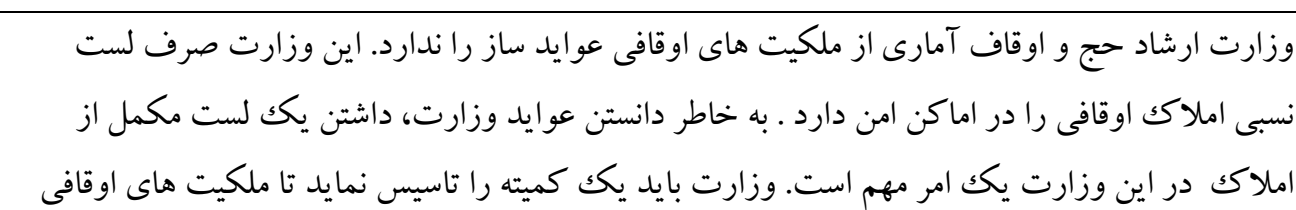 & هدف سوم & 7 \\
\hline
\end{tabular}

8 اسناد داخلى وزارت حج، جدول سيت هاى كه به مامورين عالى رتبه تخصيص يافته بو دند، رياست حج 1396

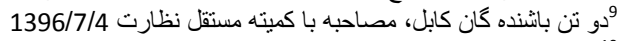
إيضاً

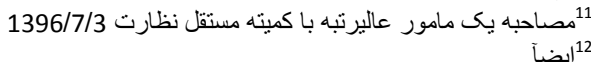




\begin{tabular}{|c|c|c|}
\hline 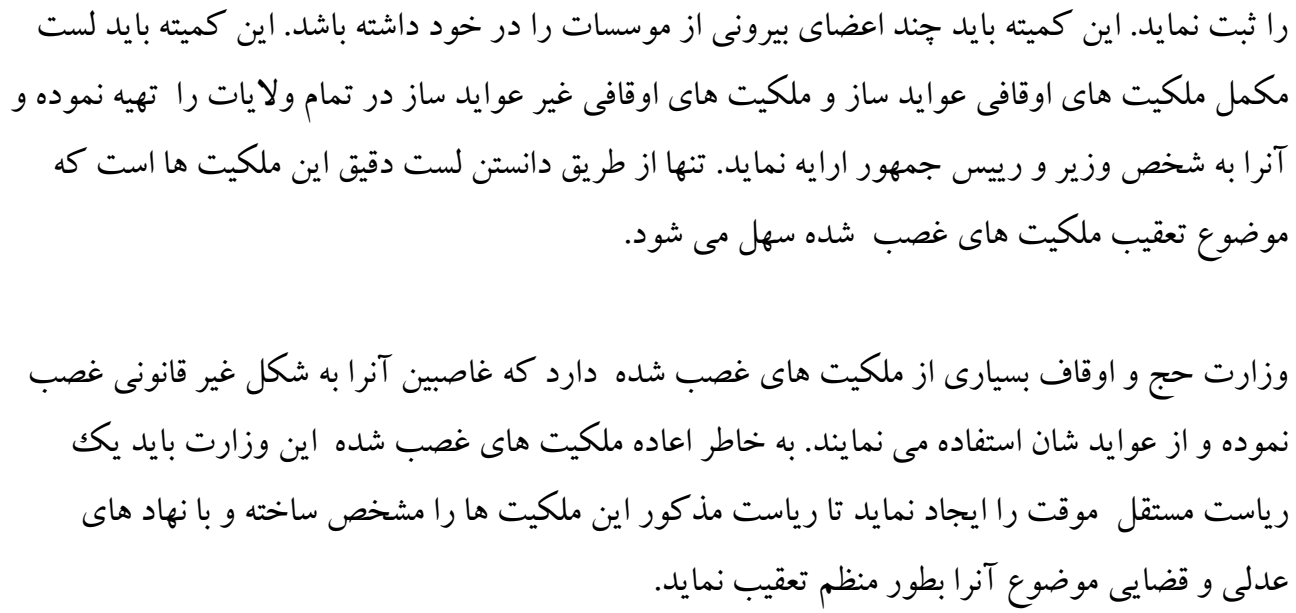 & & \\
\hline تفر بروسه تدار كات در عربستان سعودى و ولايات افغانستان رياست تفتيش داخلى غير فعال است. رياست & هدف جهارم & 8 \\
\hline
\end{tabular}

\section{سفارشات ديكر}

1. شريك سازى بِلان مبارزه با فساد با كارمندان و آموزش دهى براى آنان در اين مورد. 2. درخواست از روساى اين وزارت تا در روشنى بِلان مبارزه با فساد پِان هاى كارى شان را ايجاد نمايند. 3. راه اندازى ارزيابى شش ماه از كار كردگى وزا رت و نشر گزارشات در مورد ارزيابى در ويب سايت وزارت 4. شريك سازى ستراتيزى مبارزه با فساد ادارى با مردم از طريق كمباين هاى آكاهى عامه و نشر آن در ويب سايت. 


\section{يروسةُ انكشاف پِلان مبارزه عليه فساد ادارى}

استراتيزى ملى مباره عليه فساد ادارى(NACS) براى ادارات مختلف جهت ايجاد اصلاحات و مبارزه عليه فساد ادارى يك نقشه و راه كليدى است. مبارزه موثر بافساد ادارى نياز به پِلان جامع مباره عليه فساد ادارى دارد. يكى از راه هاى موثر غرض انكشاف يكك پِلان جامع مبارزه عليه فساد ادارى، راه اندازى ارزيابى خطر است(Risk Assessment). 14 ارزيابى خطر به نهاد ها در امر شناسايى آسيب بذيرى هاى معروض به فساد ادارى و خطرات ناشى از فساد كمكك مى نمايد و آنها را قادر ميسازد تا موارد متذكره را مديريت نموده و جهت مبارزه با آنها از قبل برنامه ريزى درست نمايند. ارزيابى بهتر خطرات منتج به مديريت موثر خطرات فساد ادارى و درنتيجه موجب ايجاد يكك پِان جامع مباره عليه فساد ادارى ميكردد.

يُلان مبارزه عليه فساد ادارى هر نهاد ادارى بايد دربر گيرندة معلومات در رابطه به جشم انداز، مرام ، اهداف و مقاصد نهاد باشد و اين كه جگگنه هر يكك از اين عناصر مبارزه عليه فساد ادارى را تسهيل مى بخشد. در پِلان مبارزه عليه فساد ادارى، هر هدف /اولويت بايد ياسخگ هُى دو سوال باشد: اول، اولويت بايد نشان دهنده مبارزه عليه فساد ادارى باشد و دوم اينكه جرا اين مورد به عنوان اولويت انتخاب گرديده است. به همين سان، فعاليت هاى كه براى هر اولويت در نظر گرفته مى شود، بايد در رابطه به رسيدگى به اولويت به حد كافى واضح و روشن باشند.

طبق اظهارات كارشناس معروف مبارزه عليه فساد ادارى، تيلمن هوٍ(Tilman Hoppe) شاخص ها، موفقيت تطبيق يروزه ر 1 سنجش مى نمايد و از اينرو براى بِلان مبارزه عليه فساد ادارى از اهميت والا برخوردار اند. شاخص هاى خوب در ارائهُ نتايج واضحتر با تأثيرات بهتر كمكك مى نمايد. بر علاوه، شاخص مفصل و دقيق در امر سنجش بهتر فعاليت هاى تكميل شده كمكك مى نمايد. طبق تيلمن هوب، جهت سنجش بهتر فعاليت ها، شاخص ها بايد داراى مشخصات آتى باشد. " شاخص ها بايد از لحاظ كيفيت و كميت

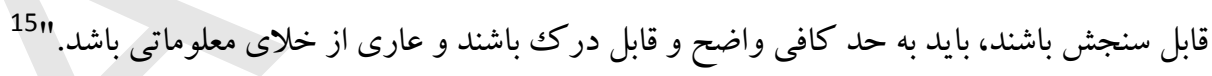

وزارت ارشاد، حج و اوقاف اداره اصلى براى حفظ عقايد و سنن اسلامى در كشور است. ماموريت وزارت متذكره به سه كتخورى عمده، كه شامل ادارهٔ امور مربوط به موعظه هاى دينى از طريق مساجد و مدارس( مدرسه ها إوهنتون ها)، اداره و تسهيل بروسهٔ سالانه

$$
\text { حج و جمع آورى عوايد اوقافى ميخردد، تقسيم مى شود. } 19
$$

هرسه كتخورى جنبه هاى قابل ملاحظةٌ مالى دارند كه در صورت عدم كنترول درست و رسيدگى به آن، ميتواند مورد فساد و استفاده جوئى قرار گيرد. غرض جلو گيرى از فساد ادارى در بخش هاى متذكره، در اين اواخر وزارت ارشاد، حج و اوقاف بِلان مبارزه عليه فساد ادارى خويش را كه شامل 4 اولويت و 19 فعاليت ميخردد، تدوين نموده است. 17

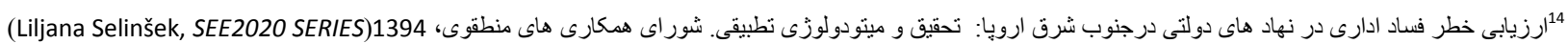


بِلان مبارزه عليه فساد ادارى بر اساس مكتوبى 18 از سوى وزارت ماليه عنوانى وزارت ارشاد، حج و اوقاف طرح گرديد. طبق مكتوب متذكره، بֶ از نشست برو كسل بيرامون افغانستان تمام وزارتخانه ها مكلف شدند تا پِلان هاى مبارزه عليه فساد ادارى خويش را تهيه و

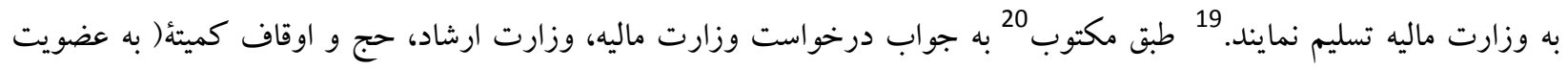
رئيس تفتيش داخلى، رئيس ارشاد و انسجام مساجد و مساجد، رئيس حج، رئيس اوقاف، رئيس منابع بشىى و رئيس بِلان و باليسى) را به وزارت ماليه معرفى نمود كه تحت صلاحيت معين ادارى و مالى ايجاد گرديده بود. به اساس مكتوب كميته مكلف است تا از تطبيق هِلان مبارزه عليه فساد ادارى نظارت بعمل آورده و گزارش ماهوارش را به وزارت ماليه ارائه نمايد. ايجاد كميتهٔ متذكره يكك ابتكار عالى از سوى وزارت ارشاد، حج و اوقاف در راستاى مبارزه عليه فساد ادارى و نظارت از تطبيق بِلان مبارزه عليه فساد ادارى اين وزارت، ميباشد.

در پِلان مبارزه عليه فساد ادارى، وزارت ارشاد، حج و اوقاف جهار اولويت/هدف را كه شامل عرضه خدمات دينى و ارشادى، عرضه خدمات حج، جمع آورى عو ايد اوقافى و عرضه خدمات ادارى و مالى بهتر در ولايات ميكردد، جا داده است.

ميتودولوزى

كميته نظارت وارزيابى مرور و بررسى بِلان مبارزه عليه فساد ادارى وزارت ارشاد، حج و اوقاف را در اوايل ماه اسد 1396 آغاز نمود. هدف از مرور و بررسى پِلان مبارزه عليه فساد ادارى وزارت متذكره اين است تا ارزيابى گردد كه آيا پِلان مزبور همه جانبه است يا خير، ساحات آسيب يذير كه حذف شده و بايد در بِلان مبارزه عليه فساد ادارى شامل ميخرديد را سفارش نمايد و از همه مهمتر ارزيابى اجرآات از تطبيق بلان مذكور در وزارت ارشاد، حج و اوقاف را ارزيابى نمايد.

براى ارزيابى بهتر پِلان بطور كُلى و دركى ساحات مشخصى كه بايد در پِلان شامل مى گُرديد، كميتهُ نظارت و ارزيابى تحقيق ثانوى را انجام داد. قسمى كه باليسى ها و طرزالعمل هاى مربوطه را در وزارت تحليل و تجزيه نموده و نيز با مقامات مصاحبه نمود. اين كميته همجينان معلومات مرتبط را از وزارت مذكور جمع آورى كرد. در كُل، كميته نظارت وارزيابى با 25 مقام از سطوح مختلف و رياست هاى مختلف وزارت ارشاد، حج و اوقاف مصاحبه نمود.

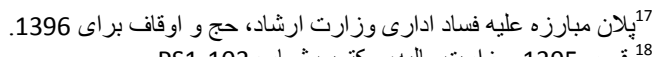

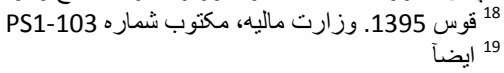
20 مكتوب شماره 1385- 10 دلو 1395. 
إفته

هدف 1

\begin{tabular}{|c|c|c|c|c|}
\hline مبدا & تاثيرات & شاخص & فعاليت & هدف \\
\hline & در آكاهى اذهان عامه از امورات دينى و & فيصلى ييشرفت & 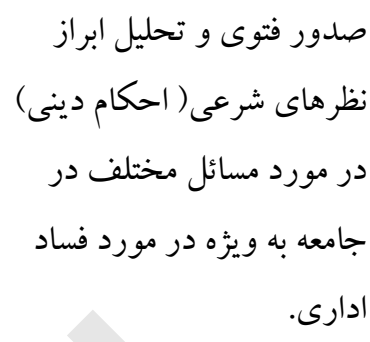 & \multirow{5}{*}{ عرضه خدمات } \\
\hline & 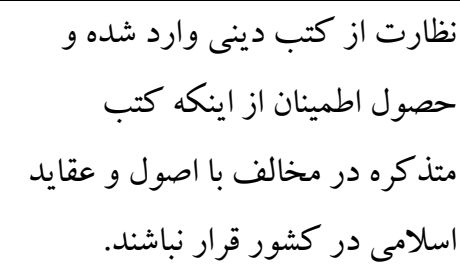 & فيصلى يشرفت & 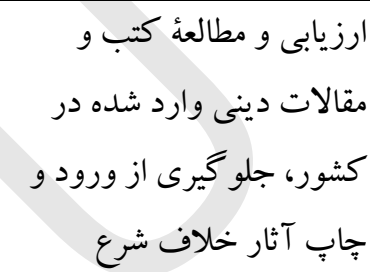 & \\
\hline & 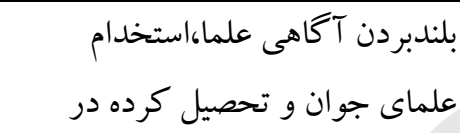 & 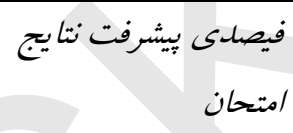 & رسلكى ازعلدازى امتحان شفاف و و خادمين & \\
\hline & جلو آكاهى عامه در از بى عدالتى ها در جامعه، & فيصلى بيشرفت نتايج & تلدوير محافل و اجتماعات & \\
\hline & آداهى عامه در مورد محو فساد & خطبدى هي بيشرفت نتايج & مسائل مختلن خطبه درن مخصو مورد & \\
\hline
\end{tabular}

يافته ها

قبل از انكشاف يِلان مبارزه عليه فساد ادارى، انجام ارزيابى خطر فساد ادارى يكك پيش نياز است. ارزيابى خطر فساد ادارى كمك ميكند تا آسيب يذيرى هاى موجود خوب درك گرديده و منتج به ايجاد يكك بِلان بهتر مى نمايد. شيوه هاى بذير فته شده نشان ميدهد كه بنج ساحهُ آتى را ميتوان در يكك پِلان مبارزه عيله فساد ادارى در نظر گرفت: بخش مالى كه شامل تدار كات و يرداخت معاشات و مديريت عوايد و وغيره موارد ميخردد، تماميت كاركنان، شفافيت اداره( نشر اسناد در ويبسايت و همجنان آنها بتوانند تا درخواست هاى شهروندان و سازمان هاى جامعه مدنى را مبنى بر ارائه معلومات بزودى طى مراحل نمايند)، مبارزه عليه فساد ادارى( خط مستقيم 
تليفونى و يا راه ديخر جمع آورى معلومات از سوى افشاكران)،استقلاليت و شفافيت نهاد هاى دخيل: نبايد مراجع و افراد غير مرتبط را اجازه دهند كه در امور و فعاليت هايشان مداخله نمايد.

در هنگام تعين اهداف براى يك يُلان مبارزه عليه فساد ادارى بايد دو سوال را در نظر گرفت: جرا اين هدف انتخاب شده است و اين هدف جه ربطى با بلان مبارزه عليه فساد ادارى دارد.

هدف فوق فقط يكى از فعاليت هاى معمول وزرات ارشاد، حج و اوقاف را تشريح مى نمايد كه همانا تشويق و ترغيب مردم از طريق موعظه ها و خدمات دينى و مذهبى ميباشد. از اينرو، هدف متذكره بيشتر به بيخيرى و اجراى فعاليت هاى روزمره و معمول در وزارت

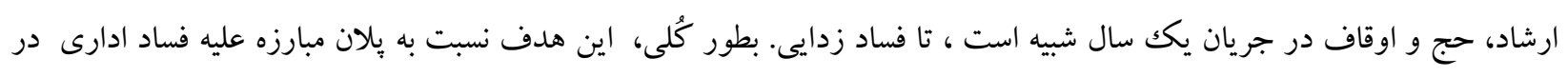
يكك هِلان عادى و غير مبارزه عليه فساد ادارى بهتر كاركر واقع ميشود. فعاليت ها بايد رابطة مشابه با هدف داشته باشند. آنها بايد به هدف و امر مبارزه عليه فساد ادارى متمركز باشند.

فعاليت اول يكى اقدامى عليه فساد ادارى است، اما تاثيرى زيادى روى مبارزه عليه فساد ادارى ندارد. اين يكك فعاليت روزمره و معمول است كه بخشى از بلان ميشود. فعاليت كه مرتبط به مبارزه عليه فساد ادارى نيست، نتيجة ملموس نخو اهد داشت. علاوه بر اين كه تأثيرات آن ملموس به نظر نمى رسد، جه كسى و جطور قادر خواهد بود كه تاثيرات آنرا در فعاليت سنجش نمايد. شاخص از لحاظ كميت قابل سنجش نيست و همجنان مشكلات كيفيتى را دارد. على الرغم مشكلات و جالش هاى تخنيكى در فعاليت، كميتهُ نظارت وارزيابى بعد از مصاحبه با مقامات معلوماتى را حاصل نمود. معلومات نشان دهنده آن است كه وزارت ارشاد، حج و اوقاف در امر

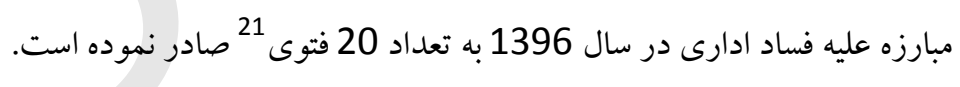

فعاليت دوم هدف، ارزيابى كتب و مقالات دينى وارد شده از خارج است. اين فعاليت كاملاً با هدف يِلان كه همانا حمايت هدف معمول است مرتبط است، اما هيج ربطى به جلو گيرى از فساد ادارى ندارد. شاخص و نتيجة فعاليت نيز با مبارزه عليه فساد ادارى مرتبط نيست. علاوه بر اين، شاخص روشن نبوده و از لحاظ كيفى و كمى قابل سنجش نيست. با وجود اين همه نواقص اين فعاليت، كميتهٔ نظارت وارزيابى فهرستى را از سوى وزارت حج و اوقاف بدست آورد كه نشان ميدهد از سال 1395 بدينسو وزارت مذكور 100

$$
\text { كتاب را مرور و بررسى نموده است. }
$$

فعاليت سوم در رابطه به استخدام امامان مساجد و راه اندازى امتحانات شفاف است. اين فعاليت به نظر ميرسد كه يك فعاليت ضد فساد ادارى و مرتبط به هدف باشد. اما شاخص روشن نبوده و از لحاظ كيفى وكمى نيز قابل سنجش نيست. على الرغم شمارى از استخدامات امامان مساجد، كميتهُ نظارت و ارزيابى بر اساس اسناد دست داشته دريافته است كه بخش منابع بشرى حدود عالمان دين را در سراسر كشور از سال 1395 الى ماه سنبلة 1396 استخدام نموده است.

221 اسناد داخلى فهرست تمام فتوى در مورد مبارزه عليه فساد ادارى، 1395-1396.

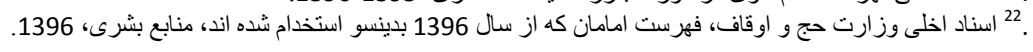


فعاليت جهارم در مورد همايش و اجتماعات ملى علما( علماى دين) براى جلو گيرى از فساد ادارى ميبشد. بحث روى تأثيرات فعاليت سخت است. هرجند فعاليت به نظر ميرسد كه با هدف مرتبط است و به يكك نوعى اقدامى است عليه فساد ادارى اما هنوز هم نتيجه اش روشن نيست. شاخص روشن نيست و از لحاظ كيفى و كمى قابل سنجش نمى باشد. طبق اسناد دست داشته، كميتهُ نظارت وارزيابى دريافته است كه سال گذشته وزارت ارشاد، حج و اوقاف 15 گردهمايى يا همايش ملى علما را راه اندازى نموده است. 23 فعاليت ينجم هيج ربطى به مبارزه عليه فساد ادارى ندارد. فعاليت متذكره در مورد خواندن خطبه(موعظه هاى دينى) براى مردم در مساجد است. اين ارائه خدمات است، نبايد به عنوان فعاليت مبارزه عليه فساد ادارى محسوب كردد. شاخص ها داراى مشكلات مشابه به فعاليت هاى قبلى اند. از لحاظ تطبيق فعاليت، طبق اسناد دست داشته كميتهُ نظارت وارزيابى، وزارت حج و اوقاف سه خطبه را در سال كذشته نشر نموده است.

به نظر ميرسد هدف و فعاليت ها بخاطر شامل پِلان گرديده است كه يكى از ماموريت هاى وزارت حج و اوقاف كار كردن روى موعظه هاى دينى براى مردم افغانستان است. با وجود اين، جنين در نظر گرفته نشده است كه هدف و فعاليت ها بايد به روى امر فساد زدايى متمر كز باشد.

\section{نتيجه كيرى}

از آنجا كه شاخص هاى فعاليت ها از لحاظ كمى و كيفى قابل سنجش نيست، آنها به حد كافى روشن نيستند، از اينرو اين بسيار سخت است كه سطح و فيصدى تطبيق را تحليل و تجزيه نمود. مرور اسناد نشان ميدهد كه وزارت ارشاد، حج و اوقاف در اجراى تمام فعاليت هاى فهرست شده براى هدف اول فعال بوده است.

هدف 2

\begin{tabular}{|c|c|c|c|c|}
\hline خط مبدا & اثر & شاخص & فعاليت & هدف \\
\hline & تامين عدالت در توزيع سهميه & فيصدى يِشرفت & توزيع عادلانه سهميه حج در و ولايات بر اساس تخمينى اداره مركزى & \multirow{3}{*}{ شرضه خدمات } \\
\hline & تهيه و تدارك سريناه مناسب و & تداركى سكى بيشرفت براى & $\begin{array}{c}\text { سعودى جهت اريئت به عربستان اخذ سكن } \\
\text { براى حجاج افغان }\end{array}$ & \\
\hline & انتقال حجاج به عربستان سعودى & فيصدى بيشرفت & انعقاد قرارداد انتقال حجاج به & \\
\hline
\end{tabular}

23 سند داخلى وزارت حج و اوقاف، مكتوب شماره 3435، فهرست تمام كردهمايى هاو همايش هاى ملى امامان /علما در سال هاى 1395-1396. 


\begin{tabular}{|c|c|c|}
\hline & انتقال حجاج & مناسب با يكى از شر كتى به قيمت \\
\hline 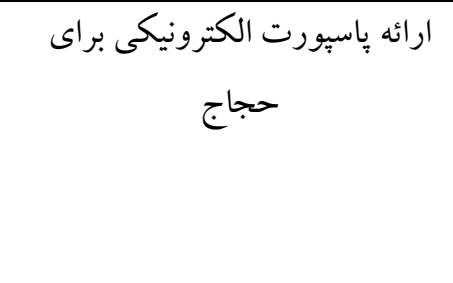 & فيصدى بيشرفت تهيه & 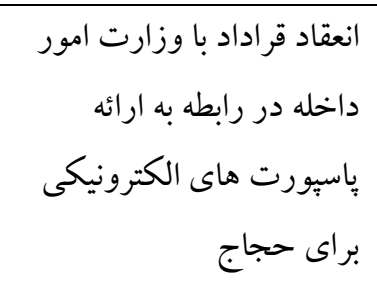 \\
\hline توزيع غذاى با كيفيت براى حجاج & فيصدى بيشرفت & جهان \\
\hline انعقاد قرارداد براى انتقال منظم & فيصدى بيشرفت & عقد قراداد جهت انتقال \\
\hline عرضه خدمات بهتر & تجهيز تجدى بيشرفت & 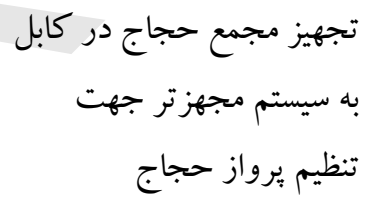 \\
\hline
\end{tabular}

يافته ها

اين هدف يلان در رابطه به فراهم نمودن خدمات بهتر حج است. خود هدف به نظر نمى رسد كه براى مبارزه عليه فساد ادارى به عنوان يكك هدف انتخاب شده باشد. اين هدف براى اين انتخاب شده كه بعضى فعاليت هاى ساده اى را ارائه دهد كه بايد در طول بروسئ حج انجام شوند. تمام فعاليت هاى فهرست شده براى اين هدف در مورد ساحات آسيب پذير به فساد در بروسهٔ حج است، اما از شيوه نغارش و جمله بندى برخى از آنها جنين معلوم نمى شود كه اقدامى عليه فساد ادارى باشند. مثال خوب فعاليت جهارم است: " انعقاد قراداد با شركت هاى غذايى در عربستان سعودى جهت فراهم نمودن غذا براى حجاج در جريان بروسهٔ حج" مى باشد. ممى شد اين فعاليت طورى نگارش گردد كه نشان دهد وزارت ارشاد حج و اوقاف در اين زمينه كوشش ميكند تا با فساد ادارى مبارزه نمايد. مثلا مى شد كه اين فعاليت جنين تحرير گررد: " نظارت و كنترول از بروسهُ تداركات براى فراهم سازى غذا در عربستان سعودى، ارسال هيئت جهت مشاهدة بروسه تا بطور شفاف انجام شود."

فقط فعاليت اول كه در رابطه به توزيع عادلانه سهميه حج است، به يروسهُ توزيع شفاف سهميه حج رسيدگى ميكند. با وجود اينكه شاخص اين فعاليت روشن و واضح به نظر نمى رسد، نمى توان آن را از لحاظ كمى و كيفى مور سنجش قرار داد، و مبهم است. با 
آنهم، كميتهُ نظارت وارزيابى دريافته است كه رياست حج در مركز سهميه حج را براى هر ولايت بر اساس نفوس موجود آن ولايت در نظر ميكيرد، بر اساس آمار و احصائ اداره احصائ مركزى(CSO)."24 براى بروسه حج در سال 1396، رياست حج سهميه حج را به تناسب نفوس هر ولايت بطور عادلانه به هر ولايت توزيع نمود. بنابراين، ميتوان گفت كه تناسب سهميه در نظر گرفته شده براى هر

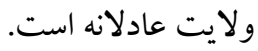

فعاليت دوم در مورد ارسال هيئت به عربستان سعودى جهت تهيه و تدار كك سريناه باكيفيت براى حجاج است. هر جند اين بسيار سخت است كه تأثير اين فعاليت را مشاهده نمود بخاطريكه شاخص هاى انتخاب شده براى اين فعاليت روشن نبوده واز لحاظ كيفى و كمى قابل سنجش نيست.ازاينرو، درك نمودن اين حقيقت ير جالش است كه منظور وزارت ارشاد حج و اوقاف از " سريناه با كيفيت" جه است. با وجود اين ، كميته نظارت و ارزيابى واقف است كه همانند سال هاى قبلى وزرات ارشاد حج و اوقاف در سال 1396 نيز يك هيئت را جهت تهيه و تداركك سريناه براى حجاج به عربستان سعودى ارسال داشته است. 25

فعاليت سوم در رابطه به انعقاد قرارداد با يكى از شركت هاى هوايى است، بار ديخر اين يكك فعاليت سالانه وزارت ارشاد، حج و اوقاف است اما مرتبط به مبارزه عليه فساد ادارى. هرجند، عبارت و جمله بندى اين فعاليت مبارزه عليه فساد ادارى را نشان نمى دهد. اما وزارت ارشاد، حج و اوقاف ميتوانست آن را دوباره عبارت بندى نمايد تا آن را با يكك اقدام خاص نظارت از شفافيت در يروسه تغيير دهد. باز هم شاخص روشن نيست و از لحاظ كمى و كيفى قابل سنجش نمى باشد و داراى خلاى معلومات است. على الرغم موجوديت مشكلات تخنيكى در فعاليت، كميتُٔ نظارت و ارزيابى تطبيق اين فعاليت را ارزيابى نمود و دريافت كه براى انتقال حجاج به عربستان سعودى وزارت ارشاد، حج و اوقاف با شركت هوايى آريانا قرارداد بسته است. طبق اسناد دست داشته، براى اين قراداد كدام اعلان يا يروسه داوطبلى انجام نشده است، زيرا قرارداد به شر كت متذكره بطور اختصاصى اعطا شده است.

فعاليت جهارم در رابطه به قراداد با وزارت امور داخله جهت فراهم سازى باسِورت هاى الكترونيكى براى كانديدان حج است. باز هم اين يكك فعاليت روزمره و معمول بروسؤ حج و غير مرتبط به امر مبارزه عليه فساد ادارى است، مخر اينكه وزارت ارشاد، حج و اوقاف آن را تغيير دهد و دوباره عبارت بندى نمايد تا اقدام ضد فساد ادارى نشان داده شود. همانند فعاليت هاى قبلى، شاخص اين فعاليت را نمى توان نه از لحاظ كمى و نه هم از لحاظ كيفى سنجش نمود. براى بروسة حج در سال 1396، وزارت ارشاد، حج و اوقاف از طريق وزارت امور داخله باسِورت هاى الكترونكى را به كانديدان حج فراهم نمود و طبق مكتوب دست داشتهٔ كميتهُ نظارت وارزيابى، رياست حج روند فراهم سازى ياسبورت هاى متذكره را به كانديدان تسهيل نموده است. 26 فعاليت ينجم در رابطه به قراداد با شر كت هاى غذايى جهت فراهم سازى غذا براى حجاج در عربستان سعودى است. شايان ذكر است كه يروسه قراداد ممكن آسيب بذيرى هاى داشته باشد و براى ايجاد يكك فعاليت بهتر، وزارت ارشاد، حج و اوقاف ميتوانست كه آن را 
قسمى نگارش كند كه بر امر فساد زدايى متمر كز باشد نه ارائه يك فعاليت انجام شده. مانند فعاليت هاى كذشته، شاخص مشكلات مشابه تخنيكى دارد. وزارت ارشاد، حج و اوقاف هيئتى را جهت فراهم سازى غذا به حجاج به عربستان سعودى اعزام داشته است. طبق كز ارش آنها و فهرست اشتراك كند كان، آنها با شر كت ها قراداد بسته اند. بنابر اين، آنان اين فعاليت را تكميل نموده اند.

فعاليت ششم در رابطه به عقد قراداد با شركت هاى ترانسبورتى است براى انتقال داخلى حجاج در عربستان سعودى است. امكان داشت كه وزارت برخى از عناصر را جهت تأمين شفافيت در يروسه اضافه نمايد. باز هم شاخص اين فعاليت روشن نيست و داراى خلاى معلوماتى است. ظرفيت اين را ندارد كه ار لحاظ كمى و كيفى سنجش شود. طبق فهرست دست داشته، كميتهُ نظارت وارزيابى دريافته است كه وزارت ارشاد، حج و اوقاف هيئتى را جهت تسهيل انتقال حجاج در عربستان سعودى اعزام داشته است.

فعاليت هفتم در رابطه به تسهيل مجتمع حجاج در كابل است. اين محل براى حجاج است كه قبل از يرواز شان به سوى عربستان سعودى و در بر گشت براى ساعاتى در آنجا اقامت نمايند. براى حجاج اين بيشتر شبيه به يك كذر گاه است، تا حجاج به اسرع وقت به برواز شان برسند و موارد ضرورى براى يرواز را بهمراه داشته باشند. 27 مانند ساير فعاليت ها، شاخص اين فعاليت نيز روشن نيست. از اينرو، براى كميتٔٔ نظارت وارزيابى دركك موضوع" تسهيل بهتر مجتمع حجاج" دشوار بود. بـ از صحبت با حجاجى 28 كه از عربستان

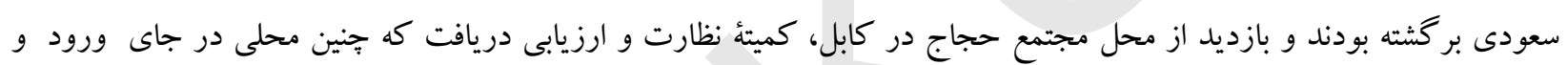
خروج حجاج قبل از برواز به عربستان سعودى و در زمان بر گشت به كابل، وجود دارد.

بطور عموم، فعاليت هاى اين هدف نياز به نظارت جدى دارد تا از هرنوع فساد احتمالى جلو گيرى صورت گيرد.اين بدين معنى است كه وزارت ارشاد، حج و اوقاف بايد يكك ميكانيزم قوى كنترول و نظارت بر تمام خدماتى كه در افغانستان و عربستان سعودى به مردم عرضه ميكند، را داشته باشد. يكى از يافته هاى كميتهُ نظارت و ارزيابى اين است كه رياست تفتيش داخلى فاقد ابزار بيشخيرانه است: ابزار و ميكانيزم هاى جلو گيرى از فساد ادارى. طبق يك نمونة گزارش تفتيش داخلى كه كميته نظارت و ارزيابى به آن دست يافته است و بِ از صحبت با مقامات رياست تفتيش داخلى 29 كميته نظارت و ارزيابى دريافت كه رياست تفتيش داخلى آن بخش ها را كه در آن مشكل عملاً در حال وقوع و يا در شرف وقوع است را مورد تفتيش قرار ميدهد. اين رياست براى جلو گيرى از جنين موارد فساد ادارى كدام ميكانيزم كنترولى و ييشگيرى را ندارد. در همكارى با رياست حج، رياست تفتيث داخلى بايد ميكانيزم هاى كنترول و نظارت را ايجاد نمايد كه در امر مبارزه واقعى عليه فساد ادارى موثر واقع گردد.

\section{نتيجه كيرى}

براى اجراى فعاليت ها، كميته نظارت وارزيابى بس از مرور و بررسى اسناد مرتبط واقف گرديد كه وزارت ارشاد، حج و اوقاف هر سال فعاليت هاى مشابهى را براى اين هدف فهرست ميكند. مقامات وزارت تمام يروسه ها راطى مراحل نموده اند تا يروسه حج را براى 
مردم افغانستان به يكك يروسه موفق مبدل نمايند. طبق معلومات فوق الذكر ميتوان كفت كه تمام فعاليت ها ذكر شده براى اين هدف تكميل گرديده است. اما بدليل اينكه شاخص هر فعاليت واضح و روشن نيست، كميتهُ نظارت و ارزيابى نتوانست فيصدى دقيقى از بيشرفت هر فعاليت را آشكار نمايد.

هدف 3

\begin{tabular}{|c|c|c|c|c|}
\hline خط مبدا & اثر & شاخص & فعاليت & هدف \\
\hline & اعادة املاكك غصافت از ملكيت هاى اوقافى و شده از غاصبين & هاى اوقافظى و ييشرفت & 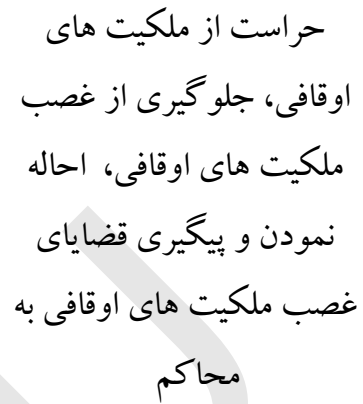 & \multirow{3}{*}{ جلمع جلو آورى عوايد و از غصب } \\
\hline & افزايش سطح عوايد اوقافى & 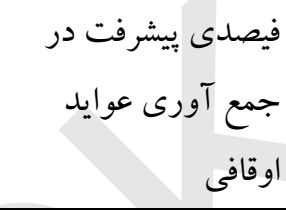 & اوفع آورى بهتر عوايد ايش در مركز و ولايات، & \\
\hline & ملكيت هيرى از تخريب اماكن مقدسه و & 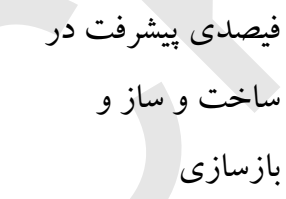 & 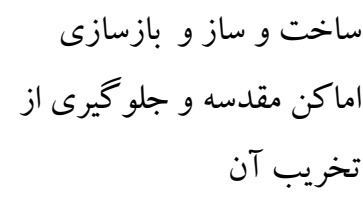 & \\
\hline
\end{tabular}

يافته ها

هدف سوم يكك هدف مبارزه عليه فساد ادارى و مرتبط به ملكيت هاى اوقافى است. 30 فعاليت نخست يك فعاليت مبارزه عليه فساد ادارى است زيرا اين فعاليت نشان دهنده حفاظت از ملكيت هاى اوقافى و جلو گيرى از غصب آن ها است و در عين زمان در راستاى اعاده و حصول دوباره ملكيت هاى غصب شده عمل ميكند. شاخص اين فعاليت كمى مبهم به نظر مير سد بخاطريكه جِگونگى محافظت از ملكيت هاى اوقافى و اينكه تا جهه حد قضايايى ملكيت هاى غصب شده را در محاكم يّيخيرى ميكند، واضح نساخته است. همجنان شاخص متذكره از لحاظ كمى و كيفى نيز قابل سنجش نمى باشد.ازاينرو، سنجش مقدار كار انجام شده امريست دشوار. باين وجود، طبق اسناد دست داشته، كميتهٔ نظارت وارزيابى دريافته است كه رياست اوقاف در حال حاضر از ملكيت هاى اوقافى خويش حفاظت ميكند و قضايايى ملكيت هاى غصب شده را در محاكم قضايى بيگيرى مى نمايد. وزارت ارشاد، حج و اوقاف، 5500 هكتار زمين اوقافى را تحت مالكيت دارد كه از آن جمله 1300 هكتار آن غصب گرديده است. مكليت هاى غصب شده در 26 ولايت كشور 
قرارد دارد. 31 رياست اوقاف بطور منظم مكاتيبى را در اين زمينه عنوانى محكمه اختصاصى كه در اين اواخر در جارجوب وزارت عدليه ايجاد گرديده، ارسال ميدارد. تا حال، وزارت ارشاد، حج و اوقاف گزارش هاى را به اين محكمه در مورد ملكيت هاى غصب شده در 18 ولايت ارسال نموده است و بروسه مذكور را از طريق ارسال مكاتيب رسمى بيخيرى مى نمايد.

فعاليت دوم در رابطه به جمع آورى بهتر عوايد اوقافى در رياست اوقاف است. اين فعاليت مطابق و مرتبط به هدف و مبارزه عليه فساد ادارى است، اما اين آشكار نيست كه وزارت ارشاد، حج و اوقاف براى جمع آورى بهتر عوايد از كدام ميتود و شيوه كار گرفته است. طوريكه تذكر يافت، شاخص مبهم بوده و نمى توان آن را از لحاظ كمى و كيفى سنجش نمود. طبق جدول واصله از رياست اوقاف، در سال 1396 عوايد اين رياست در مقايسه به سالهاى كذشته افزايش داشته است كه نشان دهندهُ جمع آورى بهتر عوايد در اين رياست ميباشد.

فعاليت سوم در مورد اعمار و بازسازى اماكن مقدسه و جلو گيرى از غصب ملكيت هاى اوقافى است. اين فعاليت در امر جمع آورى بهتر عوايد با وزارت ارشاد، حج و اوقاف كمكك مى نمايد در صورتيكه شاخص واضح و از لحاظ كمى و كيفى قابل سنجش و عارى از خلاى معلوماتى باشد.

\section{نتيجه كيرى}

يافته هاى كميته نظارت و ارزيابى نشان ميدهد كه رياست اوقاف در امر جمع آورى عوايد حاصله از ملكيت هاى اوقافى فعال بوده اما صرفاً در مناطق و ساحات كه امنيت وجود دارد. آمار و ارقام دسته داشتٔ كميته نظارت وارزيابى افزايش قابل ملاحظه عوايد را در اين رياست نشان ميدهد. هرجند عوايد متذكره از مناطق امن جمع آورى شده است. در مناطق نامن شمارى زيادى از املاكك و ملكيت هاى اوقافى بشمول دكاكين، زمين، مساجد، قبرستان ها و خانه ها در دست غاصبينى است كه آن را به نفع شخصى خود مورد استفاده قرارد داده و عوايدش را جمع آورى ميكند و حتى نزد رياست اوقاف به عنوان ملكيت هاى غصب شده ثبت نيست. يس موردى كه بالاخص براى رياست متذكره و بطور عموم براى وزارت ارشاد، حج و اوقاف بسيار لازمى است، در نخست ايجاد يك ميكانيزمى غرض تشخيص و شناسايى تمام ملكيت هاى ايشان در سراسر افغانستان و يس از آن جمع آورى عوايد آنها ميباشد. زمانيكه تمام ملكيت ها شناسايى كرديد، سبس وزارت ارشاد، حج و اوقاف ميتواند بطور قانونى ميكانيزمى بهتر را جهت حصول دوباره ملكيت هايش بكار

طبق اسناد جمع آورى شده، رياست اوقاف در امر انجام فعاليت هاى فهرست شده براى هدف فعال بوده است. از آنجايكه شاخص هاى فهرست شده براى فعاليت ها واضح و روشن نيستند، از اينرو سنجش مقدار كار كه از سوى اين رياست تكميل شده است، امريست بسيار دشوار. 
هدف 4

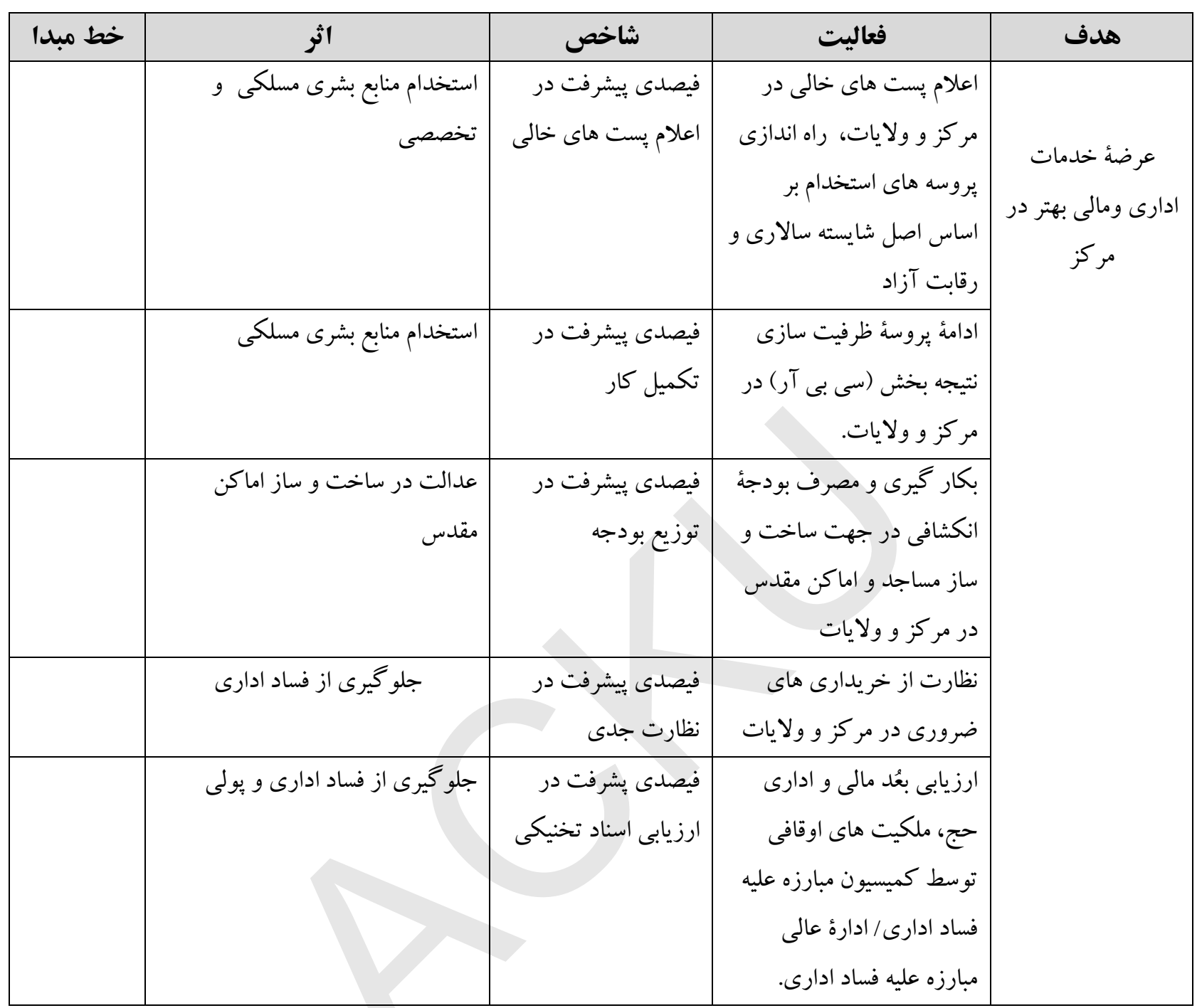

يافته ها

اين هدف در رابطه به مبارزه عليه فساد ادارى است. فعاليت اول در مورد بروسه استخدام منابع بشرى بر اساس رقابت آزاد است. اين يكك مثال خوب فعاليت مبارزه عليه فساد ادارى است اما شاخص اين فعاليت از لحاظ كمى و كيفى قابل سنجش نيست. از آنجايكه شاخص مشكلات تخنيكى دارد، تحليل و ارزيابى فيصدى كار انجام شده براى اين فعاليت دشوار بود. برعلاوه، از ماه سنبله سال 1395 بدينسو، تمام استخدام ها و مقررى هاى بست 2 الى 6 در وزارتخانه هاى بايد از سوى كميسيون مستقل اصلاحات ادارى و خدمات ملكى صورت گيرد، و به همين دليل است كه بخش منابع بشرى در سال روان هيج استخدامى نداشت، و كدام پست خالى هم موجود نبود. 
فعاليت دوم در رابطه به ادامهٔ يروسه سى بى آر است. اين شاخص مبهم بوده واز لحاظ كمى و كيفى غير قابل سنجش است. وزارت ارشاد، حج و اوقاف داراى هفت بست سى بى آر است و طبق اسناد فقط جهار بت آن تكميل/استخدام گرديده است. متباقى سه بست آن در حال طى مراحل است. بر بنياد اسناد دست داشتهُ كميتئ نظارت و ارزيابى، استخدام روساى بخش هاى مالى و ادارى، تكنالوزى معلوماتى(IT)، آكاهى عامه و تفتيش داخلى تكميل گرديده است، اما استخدام روساى بخش هاى منابع بشرى ، بِلان و باليسى و آمريت جندر هنوز هم در حال طى مراحل است. 33 بنابراين تا 5 ميزان 1396 روند متذكره 50 درصد تكميل گرديده و تا هنوز تحت كار است.

فعاليت سوم اين هدف در رابطه به مصرف بودجهُ انكشافى غرض ساخت و ساز اماكن مقدس در افغانستان است. شاخص اين فعاليت مبهم بوده و از لحاظ كمى و كيفى قابل سنجش و ندازه گيرى نيست. جدول مساجد كه طى سالهاى 1395 و 1396 از سوى وزارت، ارشاد، حج و اوقاف تعمير گُرديده نشان ميدهد كه به مبلغ 37,860,610 افغانى براى ساخت و ساز مساجد و ساير اماكن مقدس تخصيص يافته است.

فعاليت بعدى در مورد نظارت جدى از روند خريدارى در مركز و ولايات است. اين فعاليت بنظر ميرسد كه يك فعاليت خوب مبارزه عليه فساد ادارى باشد، هر جند، كميتهُ نظارت وارزيابى هيج سندى را در درست ندارد كه نشان دهندة اين امر باشد كه وزارت ارشاد، حج و اوقاف مواد خريدارى شده را در مركز و ولايات مورد نظارت قرارد داده باشد. بايد تذكر داد كه شاخص اين فعاليت همانند شاخص هاى ديخر مبهم و غير قابل سنجش است.

فعاليت ينجم در رابطه به ارزيابى تقريباً تمام دييارتمنت هاى وزارت ارشاد، حج و اوقاف توسط / ادارهٔ عالى نظارت بر تطبيق استراتيزى مبارزه عليه فساد ادارى ميباشد. از آنجايكه تطبيق اين فعاليت منوط به سازمان خارجى است، كميته نظارت وارزيابى نتواست معلوماتى را در مورد تطبيق اين فعاليت از ادارهُ عالى نظارت بدست آورد.

$$
\text { نتيجه تيرى }
$$

تطبيق ارزيابى اين هدف ممكن نبود، هرجند بر اساس معلومات دست داشته ميتوان آن را جنين ارزيابى نمود كه فعاليت متذكره بطور نيمه تطبيق شده است. 